\title{
The Socialization of a Novice Teacher of English: Becoming an Agent of Change
}

\section{La socialización de un docente novato de inglés: convirtiéndose en agente de cambio*}

\author{
Claudia Patricia Mesa Villa \\ cpatricia.mesa@udea.edu.co \\ Universidad de Antioquia, Medellín, Colombia
}

This case study reports the analysis of the induction as a socialization process of a Colombian novice teacher of English. Since critical approaches to socialization highlight the role of novice teachers in critical school transformation during their induction stage, this study aims to disclose the teacher's possibilities of becoming an agent of change. The data collection procedures included interviews, class observations and document analysis. The findings revealed that the teacher's socialization was not a gradual transition and his possibilities to contribute to school transformation differed in accordance with the interplay among his professional interests and school factors.

Key words: Agent of change, induction, novice teacher, socialization.

Este estudio de caso reporta el análisis de la inducción como socialización de un profesor de inglés novato en Colombia. Como los enfoques críticos de la socialización resaltan el papel activo de los profesores en la transformación crítica de la escuela durante su etapa de inducción, este estudio pretende dar a conocer sus posibilidades para convertirse en un agente de cambio. Los datos recolectados incluyen entrevistas, observaciones de clase y análisis documental. Los hallazgos revelaron que su

Received: June 15, 2016. Accepted: November 6, 2016.

How to cite this article (APA 6th ed.):

Mesa Villa, C. P. (2017). The socialization of a novice teacher of English: Becoming an agent of change.

HOW, 24(1), 83-100. http://dx.doi.org/10.19183/how.24.1.318.

This article is licensed under a Creative Commons Attribution-NonCommercial-NoDerivatives 4.0 International License. License Deed can be consulted at http://creativecommons.org/licenses/by-nc-nd/4.0/. 
socialización no fue una transición gradual y su participación en la transformación de la escuela variaba de acuerdo con la interacción entre sus intereses profesionales y los factores contextuales de la escuela.

Palabras clave: Agente de cambio, inducción, profesor novato, socialización.

\section{Introduction}

The shift from teacher education to professional practice is described as a "struggle to address an array of professional expectations while simultaneously being forced to make sense of the moral and often ethical friction that threatens the fragile identities formulated during their [novice teachers] time in teacher preparation programs" (Cherubini, 2009, p. 93). Due to the complexity of this phase, the analysis of teacher induction as a socialization process becomes essential to contribute to the improvement of teaching. This is how countries such as the United States, Canada, and the United Kingdom have a tradition in supporting novice teachers (Cherubini, 2009). In contrast to this trend, Calvo (2004) states that the teacher induction in Colombia has not been studied yet.

Although there is a growing tradition on exploring the professional development of EFL (English as a foreign language) teachers in Colombia, only one study has explored the experience of a novice teacher but in light of teacher autonomy (Pineda \& Frodden, 2008) and no studies have analyzed the teacher induction stage. Rather, some studies, among others, include strategies for English in-service teachers professional development (Álvarez \& Sánchez, 2005; Cárdenas, 2002; Cárdenas \& Nieto, 2010; Orrego, Quinchía Ortiz, \& Restrepo Pérez, 2005; Sierra Piedrahita, 2007a, 2007b), EFL in-service teachers development of autonomy and innovations in the classrooms (Usma \& Frodden, 2003), the needs of EFL in-service teachers (González, Montoya, \& Sierra, 2002; González \& Quinchía Ortiz, 2003) and the work of elementary EFL teachers (Cadavid Múnera, McNulty, \& Quinchía Ortiz, 2004; Cadavid Múnera, Quinchía Ortiz, \& Díaz Mosquera, 2009).

Despite the lack of studies on teacher induction in Colombia, Calvo (2004) nonetheless claims that this stage is either a lonely journey or an informal process. Besides, due to the powerful influence of school conditions on novice teachers' work (Feiman-Nemser, 2010); it becomes significant to understand how they navigate school cultures. Thus, I conducted an exploratory case study to analyze the socialization of a novice EFL teacher in an urban public school and explore his possibilities and challenges to become an agent of change. That is, his capacity of understanding political problems and working in collaboration to critically transform schools (Achinstein \& Athanases, 2010; Zeichner \& Gore, 1990).

I posed the following research question: How does the interplay between school contextual factors and the professional interests of a novice English teacher in the induction stage affect his possibilities of becoming an agent of change? 


\section{Conceptual Framework}

\section{Teacher Induction}

Induction comprises the early years of in-service teaching experience (FeimanNemser, 2010; Flores, 2010). In the area of TESOL (Teaching English to Students of Other Languages), induction has been conceptualized both in terms of years of experience and teachers' encounters with new cultural contexts (Farrell, 2012). To understand this phase, researchers and policy makers have used three conceptualizations: a formal program, a phase in learning to teach, and a socialization process (Feiman-Nemser, 2010). Regarding induction as a formal program, there is a deliberate plan to assist beginning teachers. In induction as a phase in learning to teach, emphasis is given to new teachers as situated learners. Regarding induction as a socialization process, the focus is on the interplay between teacher professional interests and school factors.

\section{Teacher Socialization}

The process in which teachers become members of an organization has been conceptualized as teacher socialization as explained next. In this phase, teachers learn the necessary knowledge, norms, and skills to participate in a particular school culture (Kelchtermans \& Ballet, 2002; Nasser-Abu Alhija \& Fresko, 2010; Zeichner \& Gore, 1990). Given the broad connotations of school culture and its central role in conceptualizing teacher socialization, several authors have defined it as a unique integration of both formal and informal schooling norms, values, accepted modes of practice and expectations in relation to behavior, relationships, and professional performance (Brunton, 2007; Cherubini, 2009; Joiner \& Edwards, 2008). Therefore, socialization involves a critical transition in which teachers may reject, accept, or adapt to the school culture, and its outcomes permeate teachers' feelings and determine their decision of staying in an organization or in the profession (Fletcher, Chang, \& Kong, 2008; Joiner \& Edwards, 2008; Nasser-Abu Alhija \& Fresko, 2010).

To comprehend socialization, Zeichner and Gore (1990) proposed three main paradigms: functionalist, interpretative, and critical. Whereas functionalist studies conceptualize socialization as a reproduction of existing structures, interpretative approaches view socialization as a process in which individuals carry out autonomous actions. The critical approach focuses on issues of power and explores individual actions that resist or negotiate structural limitations (Zeichner \& Gore, 1990). 


\section{Induction as a Socialization Process}

The vision of induction as a socialization process conceives teaching as a cultural learning practice. Several authors highlight the importance of regarding induction as a complex interplay of personal characteristics and contextual factors (Brunton, 2007; Cherubini, 2009; Feiman-Nemser, 2010; Kelchtermans \& Ballet, 2002; Nasser-Abu Alhija \& Fresko, 2010). Besides, analyzing new teachers' induction as a socialization process entails understanding how new teachers enter the profession in a particular school setting (Feiman-Nemser, 2010). In such analysis, NasserAbu Alhija and Fresko (2010) recommend conceiving schools as professional organizations in which new teachers not only acquire their practical knowledge in terms of students, colleagues, curriculum, and policies but also construct or transform their beliefs towards the profession and the institution. Cherubini (2009) highlights the conflictive nature of novice teachers' entrance to the profession since they assume proactive attitudes whereas schools function within an industrial model which demands individuals to comply with accepted professional practices.

Brunton (2007) and Nasser-Abu Alhija and Fresko (2010) draw attention to the support beginning teachers should receive. These authors claim that facing school institutional structures constitutes one of the challenges beginning teachers encounter in any organization. For this reason, induction research should address such a support, especially when school contextual factors are challenging (Curry, Jaxon, Russell, Callahan, \& Bicais, 2008). Feiman-Nemser (2010) explains that a large number of studies confirm the power of school environment on beginning teachers' actions and learning. She identifies three factors as the most influential on novice teachers' experiences: teaching assignment, access to curriculum, and relations with colleagues. As to the relation with colleagues, several authors (Kardos \& Moore Johnson, 2007; Kardos, Moore Johnson, Peske, Kauffman, \& Liu, 2001) claim that the professional cultures they encounter constitute one of the school factors with major influence on a new teacher's performance, satisfaction, and commitment.

To better understand the nature of professional cultures in schools, Kardos et al. (2001) propose three types of cultures: the veteran-oriented, the novice-oriented, and the integrated professional cultures. In the first one, novice teachers are disregarded and the priority is senior teachers' autonomy. In the second one, enthusiasm and idealism are valued, but no expert guidance is provided. Finally, in the integrated one, exchanges among novices and seniors are fostered.

\section{Setting}

The teacher participant, Andrés Salazar, ${ }^{1}$ is a Colombian secondary English teacher in his mid-twenties who graduated as a foreign language teacher in English and French from a

A pseudonym was used to protect the identity of the participant. 
public university. My role in this case study was that of an outsider who visited the school to conduct interviews and observe the teacher and the institution.

Andrés's school is a K-11 coeducational urban public institution located in a low-toupper middle class neighborhood in Medellin, the second most important city of Colombia. Authority and observance of discipline regulations are of paramount importance. For that reason, administrators and teachers are very strict in relation to regulatory compliance.

Concerning the administration, the school is led by one principal, one academic coordinator, and one discipline coordinator. Teachers are grouped into academic disciplines under the supervision of department heads. Regarding teachers, there are 37 and most have more than ten years' experience. All hold a college degree; around half hold a postgraduate certification (Especialización) and four have a master's degree. As to the English department, it is comprised of five English teachers and is led by a senior female. This department holds monthly meetings to discuss topics suggested by administrators and rarely meets outside those meetings because teachers do not have common agendas and prefer to work individually. The majority draw on traditional teaching methods such as the grammar-translation method and the teacher-centered approach.

The student body is roughly comprised of 1,400 students, 75\% boys, $25 \%$ girls, and each class is made up of about 30-40 students. The majority of them are very respectful with each other and teachers. According to observations and interviews, it was possible to conclude that, in general, students comply with school behavioral regulations such as punctuality, dressing code, and sitting arrangements but most of them hold low academic expectations.

As for the English classes, kindergarten and primary students attend two classes per week. In high school, sixth through ninth graders receive three classes, and tenth and eleventh graders are taught two weekly classes. In terms of English teaching materials, each teacher is provided with English-Spanish dictionaries and textbooks. However, the use of this textbook is not mandatory and teachers have the freedom to adapt and work around it.

In relation to the English curriculum, although teachers can make adjustments, the administrative leaders usually revise students' notebooks to monitor their implementation. The syllabus of elementary school revolves around themes such as family, classroom, and food, among others, whereas the syllabus for sixth through eleventh grades focuses on grammar. There is a strong emphasis on testing because the results serve as criteria to receive financial resources from the government.

Regarding Andrés's background, his teaching experience started when, for two years, he assisted a blind English teacher weekly in a school for disabled children and taught private English classes to adolescents. Right after college graduation, he started working as a high school English 
teacher in a private Catholic school for girls. Although he considered that his students' high academic level became a satisfying professional factor, he was not completely content with the working conditions and decided to apply for a teaching job in the public school sector.

Andrés's entrance to the public school was three months after the beginning of the school year. Despite this delay, he did not receive a formal process of induction and started teaching right away. The orientation he received consisted of two meetings with the principal and the academic coordinator, and some basic school information informally provided by a colleague who volunteered to help him.

Andrés's first teaching assignment consisted of teaching a reading comprehension course in Spanish and English to six-graders and English to tenth grade groups. In total, his load was 24 hours of class per week plus homeroom duties in a very challenging class in terms of discipline. In an interview, the principal explained that the 24 hours corresponded to the assignment of the teacher he replaced and that public school teachers are normally assigned 21 hours in addition to homeroom duties.

Regarding Andrés's views of teaching, he used to draw on a large number of teaching strategies and adapt the syllabus according to students' needs. Besides, he held liberal views on student behavior and the student-teacher relationship which contradicted the strict disciplinary and authoritarian view the school held.

\section{Method}

I developed an explanatory case study design (Yin, 2009) because it would allow me to deeply investigate Andrés's induction process as a real-life phenomenon within its context using a variety of data sources (Stake, 1995; Yin, 2009). Accordingly, I drew on interviews, observations, and documentary analysis.

\section{Data Collection}

I gained access and permission from teachers and the school administrators through consent letters and talks in which I informed them about my research procedures, information management, their role, protection of identities mechanisms, the voluntary nature of their participation; their right to refuse to answer any questions and to withdraw from the project at any time (Creswell, 2005).

Direct observations. Direct observations offer the possibility of understanding significant behaviors and typical circumstances of the case within its context (Yin, 2009). Hence, I conducted ten weekly non-participant class observations for three months to gather descriptive data about aspects such as student-teacher relationships, teachers' roles, 
classroom management skills, and teaching methodology among other school factors that play a central role during teacher induction (Feiman-Nemser, 2010). Additionally, after class observations and interviews, I used to spend a significant amount of time in the school to better understand the whole context (Toma, 2006).

Interviews. I conducted individual interviews with the participant teacher, the head of the department, one of his closest colleagues, the academic coordinator, the principal, and four group interviews with students. Concerning the teacher, I carried out four 55-65 minute in-depth interviews. The first two interviews explored his initial teaching experiences before and after graduation and his first months in the public sector. Then, after weekly observing two of his classes for two months and interviewing the principal, the academic coordinator, and the head of the department, I designed two focused interviews (Yin, 2009) with the purpose of exploring in detail certain topics about his induction that had emerged from an initial data analysis.

Regarding his colleague, the head of the department, the academic coordinator, and the principal, I conducted one in-depth individual interview with each of them. These interviews aimed to gather information about formal and informal induction processes provided to the participant up to that time. As to students, I purposefully formed four groups of students (Patton, 1990) and conducted four group interviews to explore the teacher-student relationships, teaching methodology, and teachers' roles.

Documentary analysis. I analyzed school documents such as the English syllabus, the pedagogical model, the employee handbook, the institutional evaluation system, and the quality assurance system. This document analysis aimed to gain an understanding of the school official regulations, organizational structure, and academic and administrative procedures.

\section{Data Analysis}

To analyze data, I conducted a thematic analysis following an inductive-deductive approach (Boyatzis, 1998). In addition, I used some of the procedures illustrated in Miles and Huberman (1994), Freeman (1998), and Richards (2003) such as data reduction through descriptive codes, categorization, memoing, and pattern coding. Simultaneously, I transcribed the audio-recorded interviews, formatted observations and school documents and entered them into the NVivo data management software.

The next stage consisted of reducing the data by using descriptive and interpretative codes. The last analysis phase comprised pattern coding that aimed to display similarities among categories and construct interpretations by connecting the parts into a whole (Freeman, 1998). Finally, I grouped all categories under emergent themes and concurrently built some interpretations. 


\section{Research Trustworthiness}

I followed several strategies to enhance credibility, transferability, dependability, and confirmability (Krefting, 1991; Toma, 2006). First, I triangulated the data from all sources. Second, I conducted peer examination as I shared my data analysis procedures and interpretations with my research advisor (Merriam, 1998). Third, I used member checking by taking initial and final interpretations back to the teacher participant (Merriam, 1998; Toma, 2006).

\section{Findings}

Andrés's socialization encompassed a reciprocal action among his professional interests and school contextual factors. He either ended up complying with the given school conditions, or managed to carry out some actions and make decisions that evidenced his role as an agent of change at a classroom level. In the following paragraphs, I explain such an interaction by means of two tendencies: a reactive struggle with school factors and a proactive encounter with these.

\section{Reactive Struggle With School Factors}

This tendency comprises four school factors: lack of formal induction, distant relation with administrators, lack of collaborative work among teachers, and an inappropriate teaching assignment. The existence of these factors revealed a notable disregard of Andrés's novice teacher condition on the part of the school, hindered his opportunities to make well informed decisions, and reduced his level of satisfaction, commitment, and sense of belonging to the school. Consequently, his socialization became a reactive struggle since he had to resort to either unofficial support or to devise his own solutions when trying to deal with his initial encounters with school.

Lack of induction. Data suggest that Andrés's school did not offer him any systematic induction support. School documents, informal mentorship, and newcomers themselves were the available opportunities instead. The following extract from an interview with the principal illustrates how the school leaders completely relied on school documents to guide newcomers.

with them [new teachers] an induction meeting is held, in that induction meeting, the development plan is shown, the one that is being implemented each year, the policies, criteria and the rules the school has for their performance are emphasized. . . . They are encouraged to use the site... eh the website the institution has, so by drawing on it, they analyze the curriculum and begin its implementation. ${ }^{2}$

Translated from Spanish by the author. 
Moreover, data indicate that a continuous and systematic support to ease newcomers' insertion into the specific realities of the particular school culture did not exist. Rather, informal support occurs as long as newcomers ask for help. In the following excerpt, the head of the English department describes their view about this process:

I: It means that [the induction process] is not like a program that lasts some months, but it is at the beginning?

$\mathrm{K}$ : Yes, it is done at the beginning, during about the first fifteen days.

I: And later, as the teacher goes along?

$\mathrm{K}$ : Yes, as he goes along...yes, he begins, and as he goes along, he asks in case he needs something.

I: It is like, as he goes along and he has doubts, he asks questions and you all help him?

K: Yes, exactly.

Although the school documents contained useful procedures about general administrative functioning, they did not include any practical teaching knowledge such as students' behavior and academic performance, discipline approaches, and other similar knowledge that would have helped Andrés to understand his school culture. Rather, to comprehend and learn that situated knowledge, a senior colleague played the role of an informal mentor:

She $[\text { Angie }]^{3}$ approached and explained to me everything, she showed me the school, told me how classrooms were managed because there were rotations, that is, each teacher has her/his classroom, the students were the ones who went to each classroom. She told me to visit the school website to read the syllabi to see what topics my groups were working on. (Interview, Andrés)

Relation with administrators. The inexistent ongoing assistance on the part of school administrators and the lack of any organizational procedures to favor healthy relations with administrators represented the starting point of a distant relation between Andrés and his school leaders. Moreover, since his academic coordinator constantly criticized his abilities and decisions, the interaction with this leader became problematic as explained by her colleague:

When newcomers arrive, they feel disoriented because the school is very strict, the academic coordinator has a tough character and his way of approaching new teachers is sometimes very unfriendly ... Andrés got bored because of the way the coordinator addressed him, if the administrators are giving a speech through the school intercom, you are expected to keep students completely quiet no matter how, you must shut everyone's mouth in a large group and if by chance an administrator gets to your classroom and see students speaking, you are yelled in front of the whole class. That happened to Andrés several times and that situation discouraged him a lot. (Interview, Angie)

A pseudonym was used to protect the identity of the participant. 
As to the academic coordinator's attitude toward Andrés's decisions and abilities to follow institutional norms, data indicated a constant disapproval and lack of assistance. Instead of recognizing his novice teacher status by providing him with ideas to harmonize his decisions with the school standards, this administrator resorted to strong criticisms. One example of this situation is described below:

[The principal was giving a speech on TV]. I turned the TV off because it was broken, they [students] could not hear anything. I said: "I'd better start teaching now and later on I'll ask what information she [the principal] was broadcasting so that I can inform my students." I thought it was a correct decision. But no, he [the academic coordinator] arrived in and strongly yelled at students and also yelled at me saying: "What a lack of respect with the principal, she is talking!" (Interview, Andrés)

As a result, this unhealthy relation discouraged Andrés and led him to consider the possibility of quitting his job and thereby limiting his chances of gradually and formally negotiating his own interests in relation to institutional norms and procedures. In this sense, Andres's experience is contrary to what Joiner and Edwards (2008) claim about the positive impact principals may have on novice teachers' growth. Principals can create learning opportunities such as formative observations and permanent feedback.

Lack of collaborative work among teachers. Most of Andrés's colleagues were seniors who prefer to work in isolation and thus permanent collaborative work activities such as planning or exchanging materials seemed to be disregarded by teachers and the school agenda. Angie recalled in an interview how she and Andrés once led the organization of a school cultural event and the other English teachers left them alone:

I: So, as you just said there are many senior teachers at the school.

A: Yes, and they are lazy ... and Andrés joined us and he did not find like a response, a reaction. ... Many ideas do come up, last year, he and I worked alone to prepare the English day, and we worked hard, very hard.

I: And the others?

A: No just us, because the others left. So you see? If teachers are not willing to participate, we are doing nothing.

This lack of collaboration led Andrés to assimilate his coworkers' individualistic style. Besides, this environment reduced his interest to continue working on new projects as he explains in one interview:

Right now, they [English faculty] must be thinking on what they are doing for the English day this year because I have not done anything. I have many things to do and I will not do anything else because it is not fair that some of us work hard and others don't. Although I think it would be 
nice to do something because it would be good for students so they learn and they do not end up paying the consequences of this, but if they [teachers] do not want to do anything, what can I do?

An inappropriate teaching assignment. Although Andrés's academic degree met the academic requirements of the position he was assigned, other characteristics with reference to personality, experience, and training did not fit with his initial teaching assignment. Specifically, he was assigned some challenging tasks in terms of classroom management, homeroom duties, and teaching subjects such as ethics or Spanish that were not part of his area of expertise. The administrative reasons for an initial load that was not in alignment with Andres's profile were described by the principal in an interview:

No, the teaching assignment or load cannot be modified, because you assign teachers' loads in November, [the new school year usually starts in January] so if a teacher comes in May, you cannot change their academic assignment ... . when Andrés came here teachers' assignment was ready, and he had to begin with the sixth graders. He had some difficulties because, children in sixth grade have certain characteristics in their development that require people with a lot of experience and authority.

In relation to teaching Spanish he was assigned a reading plan course but no guidance was provided. Thus, Andrés turned to students and to a personal friend who was a teacher of Spanish to know what this subject consisted of. Finally, through a trial and error process, he made decisions in terms of materials and teaching. In the following extract from an interview, Andrés describes this struggle:

A: I was told to be the teacher of reading plan, a teacher who makes students read in Spanish, last year I had to teach that subject to all sixth graders.

I: And how does it work? What does it consist of?

A: When I arrived I was told: “you are teaching reading plan in Spanish.” I thought it was similar to the private school I used to work; there, every student had a book and silently read during the whole class, but it was not like that. Here, there were not materials, they were reading some copies of Don Quixote, some were reading a chapter, others another, and so on; it was confusing and they did not understand anything, who Sancho was. I got bored and said: "I can't take this anymore." So, I asked a friend who teaches Spanish to recommend me a book and I came up with different strategies and started to try them out.

\section{Proactive Encounter With School Factors}

In this second trend, it is explained how, despite the previous factors, he managed to actively implement his own ideas and resist somehow the school culture in relation to the discipline approach, relation with students, students' low academic performance, and English curriculum at a classroom level. Thus, his socialization was not a complete reactive 
struggle but a proactive interplay among his professional interests and the school conditions as explained below.

Discipline approach. The school's discipline view represented a major conflicting factor in Andrés's socialization. Although the school culture favored authoritarianism, he views discipline as a self-regulation process and his practices about discipline revolved around dialogue. In other words, he believes that students should be encouraged to be responsible for their own learning. This is depicted by one student in the following excerpt:

He [Andrés] makes efforts so that we try to...how can I explain it? to learn, but to listen too, right? so that everything is dynamic. We don't have to be in silence looking at the board all the time; we can also chat, from time to time, so he does not mind as long as we work. (Interview, Student)

Furthermore, although Andrés made use of some traditional strategies such as rewards to encourage appropriate attitudes and penalize naughtiness with tough extra assignments, he tended to keep a conciliatory attitude when misbehavior occurred as described by one student:

He [Andrés] does not use the same tactics other teachers do: If you are doing something wrong like speaking in class or walking around, other teachers go to the office and bring the referral book. Andrés is calmer, he, instead, explains to us why we should behave well, and that's all. (Interview, Student)

Since students' discipline is of paramount importance in his school and Andrés's beliefs in relation to student behavior clearly contradicted the school expectations, staying faithful to his philosophy became one of his most strenuous acts of resistance. However, his discipline approach gained a certain level of acceptance among school leaders and students since he devised strategies that gradually turned out effective results and matched, to some extent, the school expectations such as keeping classes calm and constructing respectful student-teacher relationships.

Relation with students. Andrés's liberal attitude towards teacher-student relationships constitutes one of the crucial factors that contributed to the construction of a strong empathy with students as explained below by one student:

He is not just limited to teaching, like ah, the teacher is gone, the class is over and we will not see each other until the next class with him. Even, many times, during the break, he allows us to approach him to talk to him about not only his classes but other stuff. So, that encourages a close relationship between the student and the teacher and we do not see him like very strict and we do not feel afraid of saying... like for example, with many other teachers we feel embarrassed to ask anything different from school stuff. (Interview, Student)

In addition, Andrés's teaching, preparation, and deep knowledge of the subject matter enhanced this friendly relationship and contributed toward gaining respect among students. 
For these reasons, students held a high opinion of his work as stated by the academic coordinator in an interview:

The excellent knowledge of his subject matter, English, is one of the reasons why students have a high estimation of his work and value him.

Students' low academic performance. Raising students' motivation, academic levels, and commitment became another major challenging factor for Andrés. The excerpt below depicts his thought about this endeavor:

The challenge here is different, because here you have to motivate them and teach them that my course is more than filling out a worksheet without understanding it, they are used to doing that. In previous courses they just received a worksheet, got it marked and that's it, no matter if they did not learn anything. (Interview)

Despite students' initial low academic expectations, data show that Andrés was highly committed to help students achieve higher academic levels and become more involved. For instance, he appealed to two main actions: (1) teaching students both the contents proposed in the syllabus and exposing them to more advanced topics and (2) drawing on varied activities so that every single student became more engaged in his classes and understood the topics. The following excerpt corresponds to an eighth grader referring to Andrés' efforts:

Look, for example... what he is doing now, the topics tenth graders are studying now are similar to what we are doing, he wants us to learn more, like to be more prepared when we get to tenth grade ... he says he wants us to advance and go to college. (Interview)

Predetermined syllabus. Even if the school had a fixed syllabus, Andrés adapted it so that the new contents matched both his students' academic level and needs as well as his own interests in relation to students' performance. Specifically, the syllabus for sixth through eleventh grade was designed in alignment with the standardized national test (ICFES). Although Andrés teaching was permeated by this exam, he was allowed to adjust it as long as the predetermined topics were covered. For example, in one interview, students explained the following:

With other teachers is the same, verb to be, we also studied other topics, but it was like always grammar all the time and with Andrés we did other things like dialogues, games, and more advanced things like readings, and grammar also, but more advanced to some extent, but not only grammar because we had to understand those readings and sentences.

Given that Andrés maintained his high academic expectations all the time and his adaptations to the syllabus and methodology raised students' learning and engagement, the fact of having a predetermined syllabus became an opportunity to put into practice his teaching preparation and knowledge of the subject matter. 
Taken together, this proactive encounter with school factors went beyond a simple assimilation and involved a personal resistance and search for working conditions that matched his professional interests. Such classroom-level struggle accounts for Andrés's capacity and attitude to play the role of an agent of change since his actions and decisions evolved into well-accepted methodological adaptations, strong empathy with students, and the embracement of a liberal discipline approach that challenged the authoritarian school culture.

\section{Conclusions}

I frame my conclusions into two main aspects: induction as a socialization process and professional culture.

\section{Induction as a Socialization Process}

In countries where teacher induction has become a major concern, comprehensive programs have been designed to increase commitment, enhance collaboration, provide professional learning opportunities, and favor a proper acculturation into schools (Fletcher et al., 2008; Hudson \& Beutel, 2007; Nasser-Abu Alhija \& Fresko, 2010; Wong, Britton, \& Ganser, 2005). Conversely, in this case study, the inexistence of any structured program to support Andrés unveiled the scarce possibilities for a healthy socialization and the reductionist view that his school leaders hold in terms of induction.

This simplistic view can be also understood when analyzing Andrés's case in light of the four frames that Achinstein and Athanases (2010) propose to explain teacher induction purposes. The managerial frame focuses on the orientation in terms of school procedures and norms. In Andrés's case, this frame became evident when school leaders presupposed that handing in official documents supplied him with all the necessary elements to assume his assignments. In the humanist frame, induction aims to lessen the emotional instability. Some of the elements of this frame became apparent when Andrés's informal mentor volunteered to be his caretaker. However, this casual mentorship did not enhance situated learning as presented in the cognitive-apprentice frame. The risk behind this informal assistance and isolated learning lies in the fact that trial-and-error methods may entail a negative impact on the quality of education students receive.

Additionally, when Andrés's induction is analyzed in light of the political-critical frame (Achinstein \& Athanases, 2010) and the critical tradition of socialization (Zeichner \& Gore, 1990), his induction experience appears to be extremely inconvenient given the long-term school-reform purposes this stage should serve. These authors propose principles that envision newcomers as agents of change and such an endeavor entails the commitment of 
reform-minded teachers and a collaborative professional environment which was inexistent in Andrés's case.

\section{Professional Culture}

The predominant professional school culture becomes of paramount importance since interaction with colleagues may foster novice teachers' sense of belonging and collective responsibility for the school or, on the contrary, it may lead teachers to isolation (FeimanNemser, 2010; Kardos et al., 2001) as occurred in Andrés's case. Besides, several authors coincide on highlighting collaborative culture as one of the main predictors of job satisfaction, students' success, and desire to remain in the job (Fletcher et al., 2008; Kardos \& Moore Johnson, 2007; Nasser-Abu Alhija \& Fresko, 2010). Furthermore, in a change-oriented induction, colleagues with a critical view of education play a central role in helping novice teachers to work collaboratively towards educational change (Achinstein \& Athanases, 2010).

Specifically, Andrés's socialization was clearly permeated by a professional environment that embraced several patterns of a veteran-oriented school culture (Kardos et al., 2001) such as working in isolation and performing the minimum mandatory tasks. Therefore, this type of school cultures turns out to be very detrimental since isolation is fostered (Joiner \& Edwards, 2008; Kardos \& Moore Johnson, 2007). All this unsupportive environment risks new teachers’ desire to stay in teaching and remain at a particular school and may lead them to perpetuate the status quo through reproducing existing conditions (Zeichner \& Gore, 1990).

In short, the inexistent induction mechanisms represent a school structure that neglected Andrés's novice teacher status and his potential role as a change agent. From this circumstance, it is not difficult to infer how his school favored the reproduction of a functionalist view of socialization (Zeichner \& Gore, 1990) that led him to be immersed in a "survivalist mode" (Cherubini, 2009) and any effort to transgress this tradition entailed an isolated venture that remained at a classroom level.

\section{References}

Achinstein, B., \& Athanases, S. Z. (2010). New teacher induction and mentoring for educational change. In A. Hargreaves, A. Lieberman, M. Fullan, \& D. Hopkins (Eds.), Second international handbook of educational change (pp. 573-594). London, UK: Springer. https://doi. org/10.1007/978-90-481-2660-6_33.

Álvarez, G., \& Sánchez, C. (2005). Teachers in a public school engage in a study group to reach general agreements about a common approach to teach English. PROFILE Issues in Teachers' Professional Development, 6(1), 119-132.

Boyatzis, R. E. (1998). Transforming qualitative information: Thematic analysis and code development. Thousand Oaks, US: Sage. 
Brunton, K. (2007). Beginning teachers and their reality of teaching: Negotiating the micro-political world. Paper presented at the Ontario Bi-Annual Conference of the International Study Association on Teachers and Teaching (ISAT'T), Brock University, St. Catherines, Canada.

Cadavid Múnera, I. C., McNulty, M., \& Quinchía Ortiz, D. I. (2004). Elementary English language instruction: Colombian teachers' classroom practices. PROFILE Issues in Teachers' Professional Development, 5(1), 37-55.

Cadavid Múnera, I. C., Quinchía Ortiz, D. I., \& Díaz Mosquera, C. P. (2009). Una propuesta holística de desarrollo profesional para maestros de inglés de la básica primaria [A holistic proposal for the professional development of English language teachers at the primary level]. Íkala, Revista de Lenguaje y Cultura, 14(21), 135-158.

Calvo, G. (Coord.). (2004). La formación de los docentes en Colombia: estudio diagnóstico [Teachers' education in Colombia: A diagnostic study]. Retrieved from http://unesdoc.unesco.org/ images/0013/001399/139926s.pdf.

Cárdenas, M. L. (2002). Teacher research as a means to create teachers' communities in inservice programs. HOW, 9(2), 1-6.

Cárdenas, M. L., \& Nieto, M. C. (2010). El trabajo en red de docentes de inglés [Teachers of English network]. Bogotá, CO: Universidad Nacional de Colombia.

Cherubini, L. (2009). Reconciling the tensions of new teachers' socialization into school culture: A review of the research. Issues in Educational Research, 19(2), 83-99.

Creswell, J. W. (2005). Educational research: Planning, conducting and evaluating quantitative and qualitative research. New York, US: Pearson.

Curry, M., Jaxon, K., Russell, J. L., Callahan, M. A., \& Bicais, J. (2008). Examining the practice of beginning teachers' micropolitical literacy within professional inquiry communities. Teaching and Teacher Education, 24(3), 660-673. https://doi.org/10.1016/j.tate.2006.10.007.

Farrell, T. S. C. (2012). Novice-service language teacher development: Bridging the gap between pre-service and in-service education and development. TESOL Quarterly, 46(3), 435-449. https://doi.org/10.1002/tesq.36.

Feiman-Nemser, S. (2010). Multiple meanings of new teacher induction. In J. Wang, S. J. Odell, \& R. T. Clift (Eds.), Past, present and future research on teacher induction: An anthology for researchers, policy makers and practicioners (pp. 15-30). New York, US: Rowman and Littlefield Publishers.

Fletcher, E. C., Jr., Chang, J., \& Kong, Y. (2008, February). Organizational socialization applied to teacher induction: An emerging conceptual framework. Paper presented at the Academy of Human Resource Development International Research Conference in the Americas, Panama. Retrieved from ERIC database. (ED501599)

Flores, M. A. (2010). School cultures and organizations and teacher induction. In J. Wang, S. J. Odell, \& R. T. Clift (Eds.), Past, present and future research on teacher induction: An anthology for researchers, policy makers and practitioners (pp. 45-56). New York, US: Rowman and Littlefield Publishers. 
Freeman, D. (1998). Doing teacher- research from inquiry to understanding. Boston, US: Heinle.

González, A., Montoya, C., \& Sierra, N. (2002). What do EFL teachers seek in professional development programs? Íkala, Revista de Lenguaje y Cultura, 7(13), 29-50.

González, A., \& Quinchía Ortiz, D. I. (2003). Tomorrow's EFL teacher educators. Colombian Applied Linguistics Journal, 5, 86-99.

Hudson, S., \& Beutel, D. (2007). Teacher induction: What is really happening? Paper presented at the Australian Teacher Education Association, Wollongong, Australia. Retrieved from http:// eprints.qut.edu.au/9179/1/9179.pdf.

Joiner, S., \& Edwards, J. (2008). Novice teachers: Where are they going and why don't they stay? Journal of Cross-Disciplinary Perspectives in Education, 1(1), 36-43.

Kardos, S. M., \& Moore Johnson, S. (2007). On their own and presumed expert: New teachers' experience with their colleagues. Teachers College Record, 109(9), 2083-2106.

Kardos, S. M., Moore Johnson, S., Peske, H. G., Kauffman, D., \& Liu, E. (2001). Counting on colleagues: New teachers encounter the professional cultures of their schools. Educational Administration Quarterly, 37(2), 250-290. https://doi.org/10.1177/00131610121969316.

Kelchtermans, G., \& Ballet, K. (2002). The micropolitics of teacher induction: A narrative-biographical study on teacher socialisation. Teaching and Teacher Education, 18(1), 105-120. https:/ / doi.org/10.1016/S0742-051X(01)00053-1.

Krefting, L. (1991). Rigor in qualitative research: The assessment of trustworthiness. The American Journal of Ocupational Therapy, 45(3), 214-222. https://doi.org/10.5014/ajot.45.3.214.

Merriam, S. B. (1998). Qualitative research and case study applications in education: Revised and expanded from case study research in education. San Francisco, US: Jossey-Bass.

Miles, M. B., \& Huberman, A. M. (1994). Qualitative data analysis. Thousand Oaks, US: Sage.

Nasser-Abu Alhija, F., \& Fresko, B. (2010). Socialization of new teachers: Does induction matter? Teaching and Teacher Education, 26(8), 1592-1597. https://doi.org/10.1016/j. tate.2010.06.010.

Orrego, L. M., Quinchía Ortiz, D. I., \& Restrepo Pérez, A. I. (2005). Grupos de estudio para promover innovaciones curriculares y formarse en investigación [Study groups for the development of curricular innovation and research formation]. In I. Kostina (Ed.), La didáctica de la lengua extranjera: estado de la discusión en Colombia (pp. 1-10). Cali, CO: ICFES.

Patton, M. Q. (1990). Qualitative research and evaluation methods. London, UK: Sage.

Pineda, D., \& Frodden, C. (2008). The development of a novice teacher's autonomy in the context of EFL in Colombia. PROFILE Issues in Teachers' Professional Development, 9(1), 143-162.

Richards, K. (2003). Qualitative inquiry in TESOL. New York, US: Palgrave Macmillan. https://doi. org/10.1057/9780230505056.

Sierra Piedrahita, A. M. (2007a). Developing knowledge, skills and attitudes through a study group: A study on teachers' professional development. Íkala, Revista de Lenguaje y Cultura, 12(1), 279-305. 
Sierra Piedrahita, A. M. (2007b). The professional development of a facilitator through a study group. PROFILE Issues in Teachers' Professional Development, 8(1), 91-101.

Stake, R. E. (1995). The art of case study research. Thousand Oaks, US: Sage.

Toma, D. J. (2006). Approaching rigor in applied qualitative research. In C. F. Conrad \& R. C. Serlin (Eds.), The Sage handbook of research in education (pp. 406-423). Thousand Oaks, US: Sage. https://doi.org/10.4135/9781412976039.n23.

Usma, J., \& Frodden, C. (2003). Promoting teacher autonomy through educational innovation. Ikala, Revista de Lenguaje y Cultura, 8(14), 101-132.

Wong, H. K., Britton, T., \& Ganser, T. (2005). What the world can teach us about new teacher induction. Phi Delta Kappan, 86(5), 379-384. https://doi.org/10.1177/003172170508600509.

Yin, R. K. (2009). Case study research: Design and methods. Thousand Oaks, US: Sage.

Zeichner, K., \& Gore, J. (1990). Teacher socialization. In W. R. Houston (Ed.), Handbook of research on teacher education: A project of the Association of Teacher Educators (pp. 329-348). New York, US: Macmillan.

\section{The Author}

Claudia Patricia Mesa Villa is a teacher at the School of Languages at the Eastern Branch of the Universidad de Antioquia. She holds an MA in Foreign Language Teaching and Learning and her academic interests include teacher education, professional development, and culture in EFL.

\section{Acknowledgments}

I wish to express my deepest gratitude to my advisor, Dr. Ana María Sierra for her rigorous and continued support and to my evaluation committee, Dr. Adriana González and Dr. Rosalba Cárdenas for their invaluable insights. I owe a considerable debt to the administrators, students, and teachers of the school where this study was conducted for their selfless contributions. I am also grateful to Universidad de Antioquia for the meritbased scholarship I was awarded and to the committee, professors, and classmates of the master's program for their helpful comments. Finally, I would like to express my recognition to the master's program coordinator, Dr. Doris Correa, for her strong commitment to our education. 